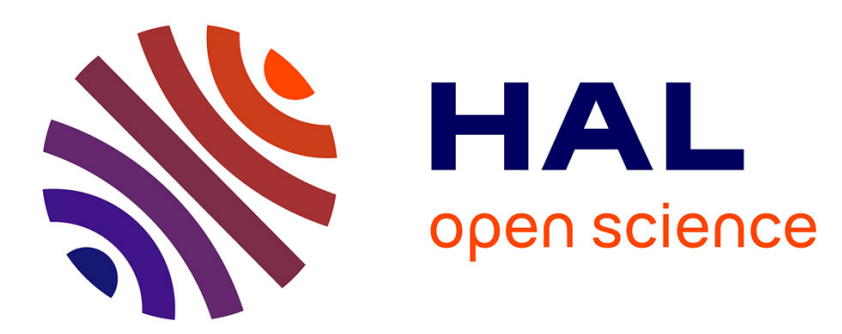

\title{
Voucher specimens for DNA sequences of Phytoseiid mites (Acari: Mesostigmata)
}

Marie-Stéphane Tixier, Mireille Okassa, Marialivia Liguori, Alix Poinso, Barbara Salerno, Serge Kreiter

\section{To cite this version:}

Marie-Stéphane Tixier, Mireille Okassa, Marialivia Liguori, Alix Poinso, Barbara Salerno, et al.. Voucher specimens for DNA sequences of Phytoseiid mites (Acari: Mesostigmata). Acarologia, 2010, 50 (4), pp.487-494. 10.1051/acarologia/20101984 . hal-01189923

\section{HAL Id: hal-01189923 \\ https://hal.science/hal-01189923}

Submitted on 1 Sep 2015

HAL is a multi-disciplinary open access archive for the deposit and dissemination of scientific research documents, whether they are published or not. The documents may come from teaching and research institutions in France or abroad, or from public or private research centers.
L'archive ouverte pluridisciplinaire HAL, est destinée au dépôt et à la diffusion de documents scientifiques de niveau recherche, publiés ou non, émanant des établissements d'enseignement et de recherche français ou étrangers, des laboratoires publics ou privés. 


\title{
VOUCHER SPECIMENS FOR DNA SEQUENCES OF PHYTOSEIID MITES (ACARI: MESOSTIGMATA)
}

\author{
Marie-Stéphane TIXIER ${ }^{1}$, Mireille OKASSA ${ }^{1}$, Marialivia LIGUORI $^{2}$, Alix POINSO ${ }^{1}$, \\ Barbara SALERNO ${ }^{3}$ and Serge KREITER ${ }^{1}$
}

(Received 07 July 2010; accepted 03 October 2010; published online 22 December 2010)

\begin{abstract}
${ }^{1}$ Montpellier SupAgro, UMR CBGP INRA/IRD/CIRAD/Montpellier SupAgro, Campus International de Baillarguet, CS 30016, 34988 Montferrier-sur-Lez cedex, France.tixier@supagro.inra.fr, okassa@supagro.inra.fr, terpsichore88@hotmail.com, kreiter@supagro.inra.fr ${ }^{2}$ Agrobiology and Pedology Research Center (CRA-ABP), 12/A Via di Lanciola,50125 Firenze, Italy. marialivia.liguori@isza.it

${ }^{3}$ University of Palermo, Dipartimento di Scienze Entomologiche, Fitopatologiche, Microbiologiche agrarie e Zootecniche (SENFIMIZO), Sezione Entomologia, Acarologia, Zoologia, Viale delle Scienze 13, 90128 Palermo, Italy. barbara-salerno@hotmail.com
\end{abstract}

ABSTRACT - Molecular approaches are increasingly used to help in species diagnostics. These approaches have been recently and successfully applied to assess some taxonomic questions within the mite family Phytoseiidae. However, many protocols for DNA extraction of such small specimens require crushing the entire sample, precluding deposition of the carcass as a museum voucher. This study aimed to determine the efficiency of a modified Qiagen DNeasy tissue kit extraction method to both extract enough DNA for performing PCR and DNA sequencing, and recover intact the adult female specimens for identification. Two types of biological material were studied for two species: $100 \%$ alcohol preserved females and females mounted in lactic acid for four hours. All specimens were retrieved after DNA extraction and were mounted on slides. All the structures used for species identification were visible with a phase microscope. DNA was successfully extracted from all the specimens considered and fragments of CytB mtDNA of 426 bp were amplified and corresponded to those of the two species considered. The Qiagen DNeasy tissue kit extraction protocol thus permits to retrieve, prepare and identify mites for which DNA has been successfully extracted, whatever the material considered: alcohol preserved or lactic acid treated mites. This result is of major interest for future taxonomic studies of the family Phytoseiidae, as it will allow the assignment of morphological and molecular attributes to a same specimen.

KEYWORDS - Neoseiulus idaeus; Typhlodromus (Typhlodromus) exhilaratus; barcoding; CytB mtDNA; voucher

\section{INTRODUCTION}

The family Phytoseiidae is the most studied family within the order Mesostigmata because of its major involvement in biological control programs. Currently, the most efficient predators of mite pests, especially those of families Tetranychidae and Eriophyidae, belong to this family (Kostianen and Hoy 1996; McMurtry and Croft 1997). Two thousand two hundred and eight species dispatched in 84 genera are reported in the last world catalogue published in 2004 (Moraes et al. 2004) and in the last revision of the family in 2007 (Chant and McMurtry 2007).

However, a high number of synonymies has been reported (i.e., more than $10 \%$ of the species described are synonyms) and many others are suspected (Moraes et al. 2004). Furthermore, morphologically cryptic species may frequently occur 
in such mite groups (Magalhães et al. 2007). To determine species validity, molecular markers are more and more used, especially in light of barcoding approaches (Hebert et al. 2003, 2004; Moritz and Cicero 2004). These concepts have been recently and successfully applied to phytoseiid mites to resolve some synonymy cases (Tixier et al. 2006a, b; 2008; Okassa et al. 2009; Kanouh et al. 2010; Okassa et al. 2010; Tixier et al. 2010). However, the main problem that taxonomists face when working from molecular-based data is the absence of voucher specimens (Rowley et al. 2007). Voucher specimens are the most important currency in taxonomy for both morphological and molecular studies, and are used for diagnostic, phylogeographic and phylogenetic analyses. Unfortunately, many protocols for DNA extraction of small specimens require crushing the entire sample, precluding deposition of the carcass as a museum voucher (Whitfield and Cameron 1994). One suggested solution is to take multiple images of the specimen before crushing (De Ley et al. 2005). However, this cannot be easily applied to phytoseiid mites as these mites have to be mounted on slides in Hoyer's medium to be identified. For now, we do not know how this mounting medium may alter DNA. Another approach is to remove a single appendage of the specimen for DNA extraction (Starks and Peters 2002). However, this cannot be used for phytoseiid mites because of their small size (less than $500 \mu \mathrm{m}$ in length), the low number of appendages and because some appendages bear specific characters essential for species identification. Another solution would be to use descendants from one female, in the case of parthogenetic organisms. However, mites of the family Phytoseiidae are strictly sexual species. Some recent studies have proposed non destructive DNA extraction methods for mites. Rowley et al. (2007) and Jeyaprakash and Hoy (2010) succeeded in extracting DNA from mites of the family Tenuipalpidae and Phytoseiidae, respectively, keeping the carcass intact for identification after the DNA extraction procedure. In these two papers, the DNA extraction method was quite complex and consisted in the use of a lysis buffer (guanidine thiocyanate [GuSCN]) followed by DNA isolation on a silica matrix. Dabert et al. (2008) and
Pakin and Vink (2009) succeeded in extracting DNA from mites of the family Xolalgidae (Acari: Astigmata) and from spiders, respectively, using a Qiagen DNAeasy tissue extraction kit. In contrast to the methods employed by Rowley et al. (2007) and Jeyaprakash and Hoy (2010), the specimens (or parts of them) were recovered before the end of the DNA extraction procedure, just after the lysis step. We currently perform DNA extraction of phytoseiid mites using the Qiagen DNeasy tissue extraction kit. This latter protocol includes a lysis step and DNA isolation using a column, and has been successfully applied to extract ancient DNA of preserved dry museology material (Badhury et al. 2007; Espeland et al. 2010). The present study aimed thus to test the combination of the two methods proposed in the litterature: (1) the use of a commercial qiagen DNA extraction kit (as Dabert et al.2008, Pakin and Vink 2009) and (2) the recovery of the carcass after the total DNA extraction procedure (Rowley et al. 2007, Jeyaprakash and Hoy 2010) for use as a voucher specimen.

Two mite materials were tested: $100 \%$ alcohol preserved females and females mounted in lactic acid. Lactic acid digests the internal tissues and clear mites so that images of the prepared material can be taken and used for partial identification (at least to the genus level) prior to DNA extraction.

\section{MATERIAL AND METHODS}

\section{Biological material}

The two species considered belong to two different sub-families: Amblyseiinae for Neoseiulus idaeus Denmark \& Muma, and Typhlodrominae for Typhlodromus (Typhlodromus) exhilaratus Ragusa. Neoseiulus idaeus was collected in Argentina (2004) on Solanum americanum Miller and T. (T.) exhilaratus on grapevine at Restinclières (Hérault, France) in 2009. These two species were mass reared in an airconditioned chamber $\left(25^{\circ} \mathrm{C}, 75 \% \mathrm{HR}, 16 \mathrm{~L} / 8 \mathrm{D}\right)$ for several months and fed on Tetranychus urticae Koch.

Two types of material were studied: (i) alcohol conserved specimens of T. (T.) exhilaratus (four females and one male) and N. idaeus (ten females) 

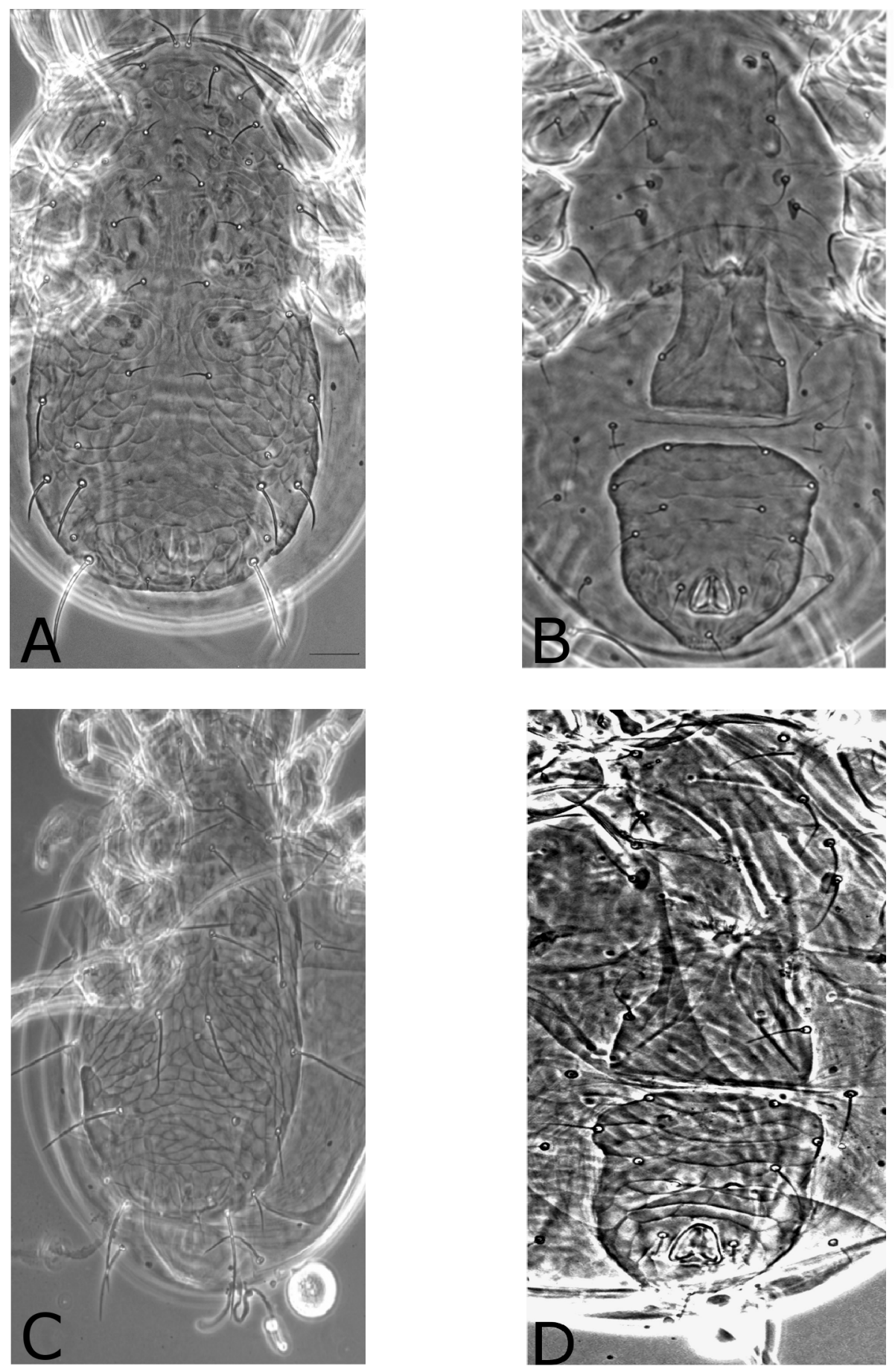

FIGURE 1: Slide-mounted females of Typhlodromus (Typhlodromus) exhilaratus and Neoseiulus idaeus after genomic DNA extraction using a Qiagen DNeasy kit. A - dorsal shield of T. (T.) exhilaratus; B - ventral shields of T. (T.) exhilaratus; C - dorsal shield of Neoseiulus idaeus; D - ventral shields of Neoseiulus idaeus.

(ii) specimens of $N$. idaeus (six females) mounted and kept in lactic acid for four hours. We choose four hours for practical purposes (mounting in the morning and observations in the afternoon). This 
duration allows sufficient time to clear mites for their identification, but longer periods are sometimes used. After four hours, the cover stip was delicately removed from the slide and the mite was collected with a fine hairbrush under a stereoscopic microscope. After observation, the mites were put in vials filled with $100 \%$ alcohol for preservation until DNA extraction. Thus, when DNA extraction was carried out, these mites were "clean" and certainly only a trace amount of lactic acid remained associated with the specimen.

\section{DNA extraction and carcass recovery}

Total genomic DNA was individually extracted from each specimen (alcohol preserved and lactic acid treated), using a Qiagen DNeasy tissue kit (Qiagen, Hilden, Germany), according to the DNA extraction protocol "Purification of Total DNA from Animal Blood or Cells" (Spin-Column Protocol) adapted for extracting total DNA from mites, especially for the lysis phase and the volumes used. To a tube containing a single mite priorly air dried, we added lysis buffer ( $90 \mu \mathrm{L}$ Phosphate-Buffered Saline), $10 \mu \mathrm{L}$ Proteinase K and $100 \mu \mathrm{L}$ Buffer AL (Qiagen). After tubes were centrifuged for $5 \mathrm{~min}$ $(13,000 \mathrm{rpm})$ and incubated at $56^{\circ} \mathrm{C}$ for $16 \mathrm{~h}, 100 \mu \mathrm{L}$ of alcohol (100\%) was added. Following centrifugation during $1 \mathrm{~min}(8,000 \mathrm{rpm})$, this mix was then deposited on a DNeasy column and centrifuged for $1 \mathrm{~min}(8,000 \mathrm{rpm})$. The collection tube and its contents were thrown away and the column was kept. The DNA on the column was then washed with 250 $\mu \mathrm{L}$ of buffer AW1 (Qiagen) which was removed by centrifuging $1 \mathrm{~min}$ at $8,000 \mathrm{rpm}$. After that, the collection tube was thrown away and a second wash was performed with $250 \mu \mathrm{L}$ of buffer AW2 (Qiagen) followed by two centrifugations of 3 min each $(13,000 \mathrm{rpm})$. Then, the DNA was eluted twice from the column using $50 \mu \mathrm{L}$ of ultra pure water and two centrifugations (1min at $8,000 \mathrm{rpm}$ each).

At the end of the DNA extraction procedure, the mite carcass, located on the top of the column, usually around the edge, was collected with a fine brush using a stereoscopic microscope. Then, the mite was mounted on a slide in Hoyer's medium and observed with a phase and differential interfer- ence contrast microscope (Leica DMLB, Leica Microsystèmes SAS, Rueil-Malmaison, France) (40x magnification). It was more difficult to retrieve lactic acid treated mites, because they were usually clearer than the alcohol preserved specimens and were therefore less visible on the white support (column).

\section{Amount of DNA}

The total amount of DNA was assessed using spectrophotometry (NanoDrop 8000, NanoDrop Technologies). DNA has maximal absorbance near 260 $\mathrm{nm}$ with an extinction coefficient of 50; whereas protein absorbs light most strongly near $280 \mathrm{~nm}$. The $\mathrm{A}_{260} / \mathrm{A}_{280}$ ratio therefore provides an estimate of DNA purity, where values of 1.8-2.0 suggest "clean DNA".

\section{Marker used}

A mitochondrial DNA marker (Cytochrome b mtDNA) was used. Primers for the amplification of this fragment were as follows: 5'-3' TAWRAARTATCAYTCDGGTTKRATATG and 3' ' $^{\prime}$ CCWTGAGGACAAATAWSWTT YTGAGG. These primers were obtained by Wannes Dermauw (University of Ghent, Belgium) for amplifying Cytb mtDNA of $P$. persimilis (W. Dermauw, pers. comm.). The PCR reaction was performed in a $25 \mu \mathrm{L}$ volume, containing $2 \mu \mathrm{L}$ of mite DNA (approximate concentration of $157 \mathrm{ng} / \mu \mathrm{L}$, D0: $260 / 280=2.05), 2.5$ $\mu \mathrm{L}(1 \mathrm{mM})$ of buffer 10X (Qiagen), $1 \mu \mathrm{L}(1.5 \mathrm{mM})$ of $\mathrm{MgCl}_{2}, 0.5 \mu \mathrm{L}$ dNTPs (0.05 mM for each nucleotide), $0.175 \mu \mathrm{L}(0.7 \mu \mathrm{m})$ for each primer, $0.125 \mu \mathrm{L}(0.625 \mathrm{U})$ of Taq Qiagen and $18.525 \mu \mathrm{L}$ of water. Thermal cycling conditions were as follows: $94{ }^{\circ} \mathrm{C}$ for $3 \mathrm{~min}$, followed by 35 cycles of $92{ }^{\circ} \mathrm{C}$ for $20 \mathrm{~s}, 53{ }^{\circ} \mathrm{C}$ for 1 min and $72{ }^{\circ} \mathrm{C}$ for $1 \mathrm{~min}$, and an additional $5 \mathrm{~min}$ at $72{ }^{\circ} \mathrm{C}$ (Okassa et al. 2010). Amplified DNA was visualized by electrophoresis using $4 \mu \mathrm{L}$ of the PCR reaction on a $1.5 \%$ agarose gel in $0.5 \mathrm{X}$ TBE buffer (migration of $30 \mathrm{~min}$ at 100 volts).

\section{DNA sequencing}

In order to check that the PCR products obtained corresponded to phytoseiid mite DNA, 
PCR products were sequenced using Dynamic ET Terminator Cycle Sequencing kit, and purified using ExoSAP-IT (Amersham Biosciences, GE Heathcare, Piscataway, NJ, USA). The sequencer used was the Megabase 1,000 apparatus (http:/ / www.gelifesciences.com/aptrix/upp01077 .nsf/content/autodna_megabace1000). DNA fragments were sequenced in both directions and were aligned and analysed with Mega 4.1 (Tamura et al. 2007). Accession numbers of sequences in Genbank database are shown in table 1.

\section{RESULTS}
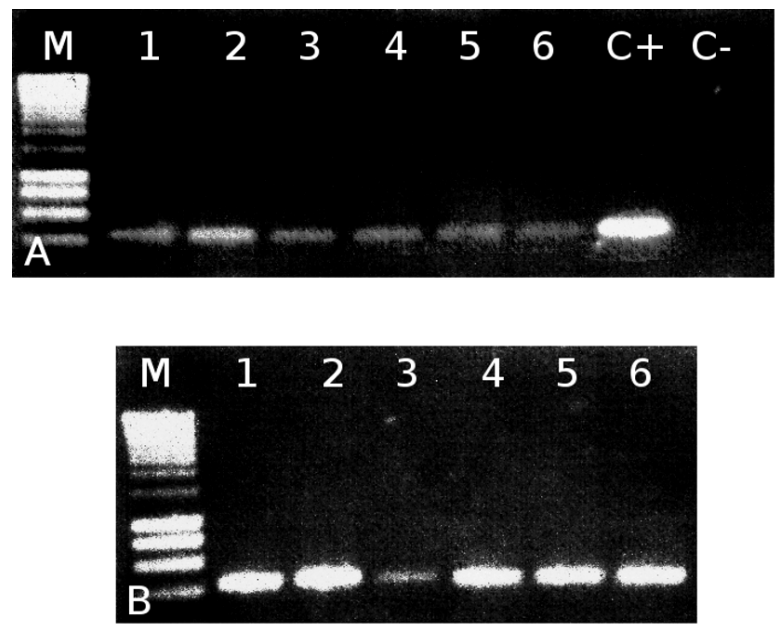

FIGURE 2: DNA bands of the expected sizes were amplified for the mitochondrial Cytb fragment from A - Neoseiulus idaeus, from B - from Typhlodromus (Typhlodromus) exhilaratus. A Lane $\mathrm{M}$ shows the molecular weight marker, $\mathrm{C}$ indicates the water control, $\mathrm{C}+$ indicates the positive control, lanes 1-6 show the PCR products of a single $N$. idaeus specimen preliminarily treated with lactic acid. Image B: Lane M shows the molecular weight marker, Lanes 1-5 show the PCR products of a single T. (T.) exhilaratus specimen conserved in $100 \%$ alcohol.

For the two types of mite material and the two species considered, all the specimens were retrieved on the columns after DNA extraction and all were mounted on slides. The figure 1 shows the dorsal and ventral shields of these specimens after DNA extraction. All structures used for species identification are visible; in rare cases (and only for mites treated with lactic acid) some dorsal setae were broken preventing measurements. The Qiagen kit pro- tocol thus permits to retrieve, prepare and identify mites after DNA extraction, regardless of the material considered (alcohol or lactic acid treated mites).

Fragments of 426 base pairs (bp) were successfully amplified for all specimens (Figure 2). A BLAST search on the Genbank database and on our own DNA sequence database showed that the obtained sequences aligned with other $\mathrm{Cytb}$ sequences of the two species considered: N. idaeus and T. (T.) exhilaratus.

\section{DISCUSSION}

\section{Access of voucher specimens}

In agreement with results obtained by Jeyaprakash and Hoy (2010) and Rowley et al. (2007), the present study shows that it is possible to extract DNA from phytoseiid mite females and to preserve the carcass as a voucher specimen for the identification of morphological characters. The Qiagen DNeasy tissue kit thus seems to perform as well as the protocols proposed by these other authors. Unlike the protocols proposed by Dabert et al. (2008) and Pakin and Vink (2009), here, the specimens were retrieved at the end of the extraction procedure and not only after the lysis phase. The outlined method therefore provides a simple and rapid DNA extraction protocol for these mites.

Only two species were examined in the present study and DNA extraction success could vary according to mite size. However, we are quite confident that outlined method would apply equally well for other phytoseiid mite species, even smaller ones. Indeed, we have shown in a recent paper (Okassa et al. submitted) that the DNA extraction method we propose here allows to successfully extract DNA from eggs, larvae, protonymphs, deutonymphs and males of Phytoseiidae. Furthermore, since the development of this method, we have used it for recover voucher specimens of several Phytoseiidae species (data not shown). This approach could also be applied to other mite families; successful DNA extraction of one specimen of T. urticae (family Tetranychidae) was also performed using this same protocol (data not shown). The carcass of this mite was retrieved and identified, and 
the DNA was successfully sequenced. However, additional investigations are required to quantify the adequacy of the present protocol for other mite families, in accordance with the required identification specificities of each group.

These results open new perspectives for Phytoseiidae taxonomy, but also for other mite families. Indeed, the accurate association of molecular and morphological attributes of a same specimen will be of great help in various taxonomic studies, including phylogenetic analyses and species identification (barcoding), particularly in the case of cryptic species (Magalhaes et al. 2007). Until now, Phytoseiidae specimens designated as vouchers were selected from the same series of specimens (same population, locality, and collection date) as those used for DNA extractions. These specimens were mounted on slides, identified and conserved in the mite collection. However, this method led to sev- eral problems. When specimens of several species were found in a same sample (e.g., on the same plant in a same locality), it was impossible to determine to which species the sequenced species belonged. Thus, such samples were discarded regardless of their potential interest for specific systematic aims. Furthermore, even when only one species was present, this method limited the assessment of intraspecific variation, both for morphological and molecular analyses, as the number of specimens studied with the two approaches was obligatorily divided by two.

\section{Acid lactic treatment and preliminary identification}

The present study shows that it is also possible to extract DNA from mites preliminarily treated with lactic acid and to recover the carcass for a full mite identification afterwards. Lactic acid treatment

TABLE 1: Specimens and species considered and their accession numbers in Genbank.

\begin{tabular}{cccc}
\hline Species & Stage & Specimen treatment & $\begin{array}{c}\text { Accession numbers in } \\
\text { Genbank }\end{array}$ \\
\hline Typhlodromus (Typhlodromus) exhilaratus & female & alcohol conservation & HQ449405 \\
Typhlodromus (Typhlodromus) exhilaratus & female & alcohol conservation & HQ449406 \\
Typhlodromus (Typhlodromus) exhilaratus & female & alcohol conservation & HQ449407 \\
Typhlodromus (Typhlodromus) exhilaratus & female & alcohol conservation & HQ449408 \\
Typhlodromus (Typhlodromus) exhilaratus & male & alcohol conservation & HQ449409 \\
Neoseiulus idaeus & female & alcohol conservation & HQ449410 \\
Neoseiulus idaeus & female & alcohol conservation & HQ449411 \\
Neoseiulus idaeus & female & alcohol conservation & HQ449412 \\
Neoseiulus idaeus & female & alcohol conservation & HQ449413 \\
Neoseiulus idaeus & female & alcohol conservation & HQ449414 \\
Neoseiulus idaeus & female & alcohol conservation & HQ449415 \\
Neoseiulus idaeus & female & alcohol conservation & HQ449416 \\
Neoseiulus idaeus & female & alcohol conservation & HQ449417 \\
Neoseiulus idaeus & female & alcohol conservation & HQ449418 \\
Neoseiulus idaeus & female & alcohol conservation & HQ449419 \\
Neoseiulus idaeus & female & lactic acid & HQ449420 \\
Neoseiulus idaeus & female & lactic acid & HQ449421 \\
Neoseiulus idaeus & female & lactic acid & HQ449422 \\
Neoseiulus idaeus & female & lactic acid & HQ449423 \\
Neoseiulus idaeus & female & lactic acid & HQ449424 \\
Neoseiulus idaeus & female & lactic acid & HQ449425 \\
\hline
\end{tabular}


clears the mite tissue, a step required to observe the structures used for species identification. After this treatment, it is possible to identify the mites (at least to the genus level) before performing DNA extractions. This is particularly important because of the relatively high cost of the Qiagen DNeasy tissue extraction kit. Preparing the mites in lactic acid enables one to observe them before DNA extraction, and therefore to select only those specimens of the species/genus of interest.

\section{CONCLUSION}

The application of recently developed molecular techniques is very important for the taxonomy of Phytoseiidae, opening new insights and facilitating in-depth studies of this group. Nevertheless, additional studies dealing with the DNA extraction of specimens from museum collections would be required to make systematic studies of phytoseiid mites even easier. Natural history collections are an invaluable source of biological data, including molecular data (Espeland et al. 2010). It is often easier to obtain a mite specimen from collections than to collect it in the field, particularly in remote regions of the world. Indeed, in field collections, the species expected is sometimes no longer present in the locality from where it was initially reported (due to local extinction of taxa and/or habitat loss). Phytoseiid mite collections consist in specimens mounted on slides in Hoyer's solution, a medium which contains arabic gum (30.0 g), water $(50.0 \mathrm{ml})$, chloral hydrate $(200.0 \mathrm{~g})$ and glycerol (16.0 $\mathrm{ml})$. Chloral hydrate, the main component of this medium, is a clearing agent of chitin that can alter DNA. Some preliminary tests carried out on slidemounted mites (recent or ten years old) using the present methodology did not have positive results; PCR products were obtained, but all corresponded to human DNA (i.e., contaminations). The development of protocols that enable the extraction, amplification and sequencing of ancient DNA from these organisms are therefore required in order to be able to use museum mite collections for molecular taxonomic studies.

\section{ACKNOWLEDGEMENTS}

The involvement of Marialivia Liguori in this study was possible thanks to the CRA Guest Fellowships, Programme 2009.

\section{REFERENCES}

Badhury P., Austen M.C., Bilton D.T., Lambshead P.J.D., Rogers A.D., Smerdon G.R. 2007 - Exploitation of archived marine nematodes, a hot lysis DNA extraction protocol for molecular studies - Zool. Scr., 36: 93 -98 .

Chant D.A., McMurtry J.A. 2007 - Illustrated keys and diagnoses for the genera and subgenera of the Phytoseiidae of the world (Acari: Mesostigmata). Indira Publishing House, 220 pp.

Dabert J., Ehrnsberger R., Dabert M. 2008 - Glaucalges tytonis sp. n. (Analgoidea, Xolalgidae) from the barn owl Tyto alba (Strigiformes, Tytonidae): compiling morphology with DNA barcode data for taxon descriptions in mites (Acari) - Zootaxa, 1719: 41-52.

De Ley P., De Ley I.T., Morris K., Abebe E., MundoOcampo M., Yoder M., Heras J., Waumann D., RochaOlivares A., Burr J.A.H., Baldwin J.G., Thomas W.K. 2005 - An Integrated Approach to Fast and Informative Morphological Vouchering of Nematodes for Applications in Molecular Barcoding - Philos. Trans. R. Soc. Lond. B. Biol. Sci. B., 360: 1945-1958.

Espeland M., Irestedt M., Johanson K.A., Åkerlund M., Bergh J.-E., Källersjö M. 2010 - Dichlorvos exposure impedes extraction and amplification of DNA from insects in museum collections - Front. Zool., 7: 2-8.

Hebert P.D.N., Cywinska A., Ball S.L., deWaard J.R. 2003 - Biological identifications through DNA barcodes Proc. R.1 Soc. Biol. Sci., 270: 313-321.

Hebert P.D.N, Stoeckle M.Y., Zemlak T.S., Francis C.M. 2004 - Identification of birds through DNA barcodes — PLoS Biol., 2(10): 312.

Jeyaprakash A., Hoy M.A. 2010 - A DNA extraction procedure that allows mite specimens to be slide mounted: phytoseiid species evaluated as a model Exp. Appl. Acarol., Doi 10.1007/s10493-010-9357-9.

Kanouh M., Tixier M.-S., Guichou S., Cheval B., Kreiter S. 2010 - Two synonymy cases within the genus Neoseiulella (Acari: Phytoseiidae): is the molecular evidence so evident? - Biol. J. Linn. Soc., 101: 323-344.

Kostiainen T.S., Hoy M.A. 1996 - The Phytoseiidae as biological control agents of pest mites and insects. A bibliography. Monograph 17, Gainesville. University of Florida, Agricultural Experiment Station, Institute of Food and Agricultural Sciences, 355 pp. 
Magalhães S., Forbes M.R., Skoracka A., Osakabe M., Chevillon C., McCoy K. 2007 - Host race formation in the Acari - Exp. Appl. Acarol., 42(4): 225-238.

McMurtry J.A., Croft B.A. 1997 - Life-styles of phytoseiid mites and their roles in biological control - Ann. Rev. Entomol., 42: 291-321.

Moritz C., Cicero C. 2004 - DNA barcoding: promise and pitfalls - PloS Biol., 2: 1529-1531.

Moraes G.J. de, McMurtry J.A., Denmark H.A., Campos C.B. 2004 - A revised catalog of the mite family Phytoseiidae - Zootaxa, 434: 1-494.

Okassa M., Tixier M.-S., Cheval B., Kreiter S. 2009 - Molecular and morphological evidence for new species status within the genus Euseius (Acari: Phytoseiidae) - Can. J. Zool., 87: 689-698.

Okassa M., Tixier M.-S., Kreiter S. 2010 - The use of two mitochondrial DNA fragments (12S rDNA and Cytb mtDNA) for assessing the diagnosis of Phytoseiulus persimilis Athias-Henriot and Phytoseiulus macropilis (Banks) (Acari: Phytoseiidae) - Exp. Appl. Acarol. on line first doi: 10.1017/s10493-010-9364-.

Pakin P., Vink C.J. 2009 - Testing compatibility between molecular and morphological techniques for arthropod systematics: a minimally destructive DNA extraction method that preserves morphological integrity, and the effect of lactic acid on DNA quality - J. Insect conserv., 13: 453-457.

Rowley D.L., Coddington J.A., Gates M.W., Norrbom A.L., Ochoa R.A., Vandenberg N.J., Greenstone M.H. 2007 - Vouchering DNA-barcoded specimens: test of a non destructive extraction protocol for terrestrial arthropods - Mol. Ecol. Notes, 7: 915-924.

Starks P.T., Peters J.M. 2002 - Semi-non destructive genetic sampling from live eu-social wasps, Polistes dominulus and Polistes fuscus - Insectes Sociaux, 49: 20-22.
Tamura K., Dudley J., Nei M., Kumar S. 2007 - MEGA4: Molecular Evolutionary Genetics Analysis (MEGA) software version 4.0 - Mol. Biol. Evol., 24: 1596-1599.

Tixier M.-S., Kreiter S., Barbar Z., Ragusa S., Cheval B. 2006a - The status of two cryptic species: Typhlodromus exhilaratus Ragusa and Typhlodromus phialatus Athias-Henriot (Acari: Phytoseiidae): consequences for taxonomy - Zool. Scr., 35: 115-122.

Tixier M.-S., Kreiter S., Ferragut F., Cheval B. 2006b - Morphological and molecular evidences for the synonymy of Kampimodromus hmiminai McMurtry \& Bounfour and K. adrianae Ferragut \& Pena-Estevez (Acari: Phytoseiidae) - Can. J. Zool., 84 (8): 12161222.

Tixier M.-S., Kreiter S., Croft B.A., Cheval B. 2008 Kampimodromus aberrans (Acari: Phytoseiidae) from USA: morphological and molecular assessment of its identity - Bull. Entomol. Res., 98: 125-134.

Tixier M.-S., Ferrero M., Okassa M., Guichou S., Kreiter S. 2010 - Morphological and molecular analyses of four populations of Phytoseiulus longipes (Mesostigmata: Phytoseiidae) in accordance with their feeding behaviour - Bull. Entomol. Res., 100(5): 569-579. doi:10.1017/S0007485309990617.

Whitfield J.B., Cameron S.A. 1994 - Museum policies concerning specimen loans for molecular systematic research - Mol. Phylogen. Evol., 3: 268-269.

\section{COPYRIGHT}

$((c)$ EY-No-ND Tixier et al.. Acarologia is under free license. This open-access article is distributed under the terms of the Creative Commons-BY-NC-ND which permits unrestricted non-commercial use, distribution, and reproduction in any medium, provided the original author and source are credited. 